
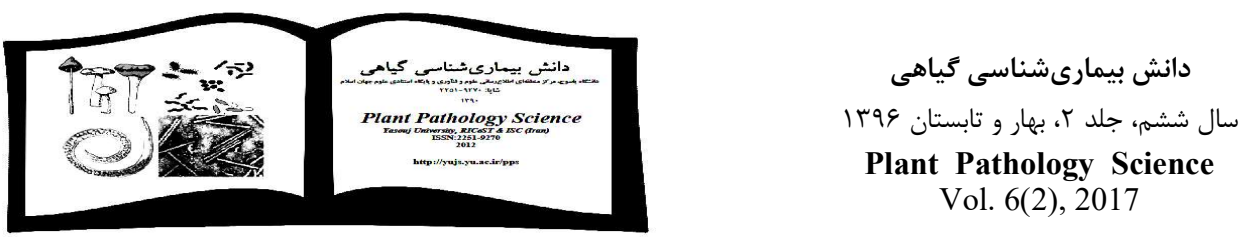

\title{
Plants Defense Mechanisms Against Pathogens
}

JALAL GHOLAMNEJAD

Ardakan University, Ardakan, Iran (jgholamnezhad@ardakan.ac.ir)

Received: 03.05.2016

Accepted: 28.04.2017

Gholamnejad J. 2017. Plants defense mechanisms against pathogens. Plant Pathology Science $6(2): 24-32$.

Abstract: Plants have many defense mechanisms against pathogens that can be stimulated and activated by some microorganisms or chemicals. There are five types of induced resistance in plants that are included: localized acquired resistance, systemic acquired resistance, systemic gene silencing, induced systemic resistance, and systemic wounding response. Systemic acquired resistance is the most important type of induced resistance in plants that result in continuous and prolonged protection from infection against a wide range of pathogens. Formation of pathogenesis related proteins, alteration of cell wall with sedimentation and binding of polysaccharides, proteins, glycol-proteins, phenols, phytotoxins, and ligninification are the stages of occurrence of this type of resistance in plants.

Key words: Protein, Peroxidase, Lignin, Induced resistance

$$
\begin{aligned}
& \text { سازوكارهاى دفاعى گياهان در برابر بيماركرها } \\
& \text { جلال غلامنزاد } \\
& \text { دانشعاه اردكان }
\end{aligned}
$$

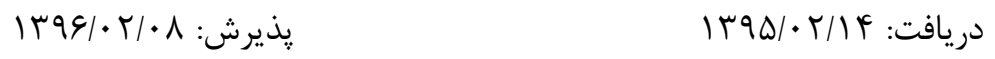

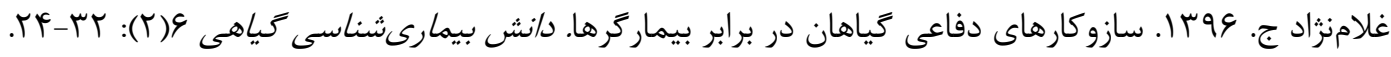

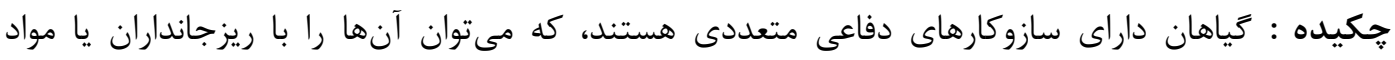

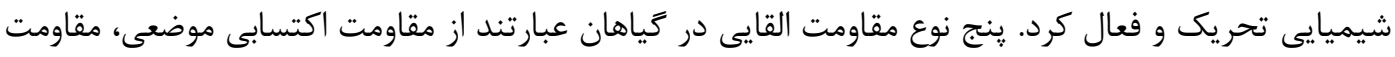

$$
\begin{aligned}
& \text { اكتسابى سيستميك، تنظيم سيستميك خاموشى زنها، مقاومت سيستميك القاشده و و واكنش سيستميك إنى }
\end{aligned}
$$

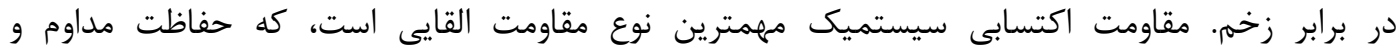

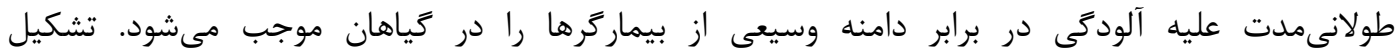

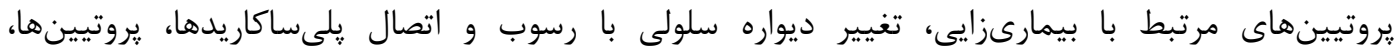

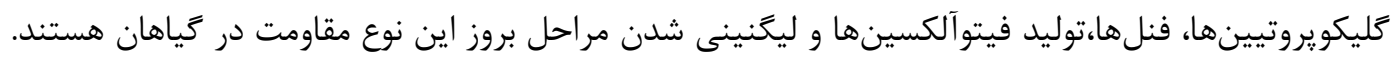

$$
\begin{aligned}
& \text { وازههاى كليدى: يروتيين، براكسيداز، ليحنين، مقاومت القايى }
\end{aligned}
$$


گياهان در برابر اغلب بيمار گرها سازوكارهاى دفاعى متعددى دارند. القاى مقاومت در گياهان سالهاى

طولانى است كه شناختهشده است. القاى مقاومت به معنى بالا بردن مقاومت گياه با تحريك سيستم دفاعى آن توسط يك محرك است. محركين مقاومت مىتوانند يك ماده شيميايى يا يك جاندار باشند

.(Farhbakhesh and Massah 2015, Mandal 2010)

\section{ا - انواع مقاومت القايى در كياهان}

1-1- مقاومت اكتسابى موضعى (Localized acquired resistance= LAR) : در اثر تماس محرك با بافت

كياه سازو كارهاى واكنش فوقحساسيت (Hypersensitivity reaction=HR) به بيماركر در همان محل هاى

$$
\text { تماس، به صورت موضعى فعال مىشوند. }
$$

1-ז- مقاومت اكتسابى سيستميك (Systemic acquired resistance= SAR) : در اثر تماس محرك،

$$
\text { مقاومت نسبى به بيماركر در تمام بافتهاى گياه به وجود مى آيد. }
$$

ا- ז- تنظيم سيستميك خاموشى زنها (Systemic gene silencing= SGS): در اين نوع القاى مقاومت

كروهى از زنها كه قبلاً خاموش بودند، فعال مىشوند و شروع به بيان شدن مى كنند. بهطور مثال اكر كياهى به ويروس آلوده شود و اين آلوده شدن در بخشهاى يايينى گياه باشد مىتواند اين مقاومت را در بخشهاى بالايى خود هم نشان دهد. البته اين بيان شدن در نهايت باعث ايجاد مقاومت اكتسابى عمومى (SAR) مىشود.

1- ا- مقاومت سيستميك القاشده (Induced systemic resistance= ISR): اين نوع مقاومت بهوسيله

$$
\text { باكترىهاى تحريك كننده رشد بهصورت سيستميك در بعضى گياهان به وجود مىآيد. }
$$

1-ه - واكنش سيستميك در برابر زخم (Systemic wounding response=SWR) : اين نوع مقاومت

$$
\text { بلوسيله زخمهايى كه غالباً بر اثر حشرات در كَياه به وجود مى آيند، ايجاد مىشود. }
$$

يزوهشهايى در مورد القاى مقاومت به بيمارىهاى يس از برداشت صورت كرفته است. در يكى با

استفاده از دو مخمر Rhodotorula mucilaginosa Candida membranifaciens ، سيستم دفاعى ميوه

سيب در برابر عامل كيك آبى (Penicillium expansum) تحريك شده است (Gholamnejad et al. 2010). 


\section{r- انواع مقاومت گياهان در برابر بيماركرها}

ץ-1- مقاومت غيرميزبانى: مقاومت غيرميزبانى عموماً در مورد تمام زنوتيڤهاى گوناگون يك بيماركر در برهمكنش با همه گونههاى يك گياه ناسازگًار گفته مىشود. در اين نوع مقاومت گياه ميزبان بيمارگر نبوده و در برابر حمله آن مصون است (Senthil-Kumar and Mysore 2013, Jafary et al. 2008). ץ-Y- مقاومت اختصاصى ميزبان: اين مقاومت در گياهان با عدم توانايى بيمارگر براى رشد و گسترش و در بعضى موارد با واكنش فوق حساسيت مشخص مىشود. اين نوع مقاومت همان گونه كه كفته شد مقاومت اكتسابى موضعى (LAR) ناميده مىشود. مقاومت سيستميك اكتسابى (SAR) حفاظت مداوم و طولانىمدت عليه آلودگى در برابر دامنه وسيعى از بيماركرها را به دنبال دارد. مقاومت سيستميك اكتسابى در بافتهايى به وجود مى آيد كه با محل نفوذ بيمارگر فاصله داشته باشند و اين نوع از مقاومت در برابر طيف وسيعى از بيماركرها وجود دارد (Truman et al. 2006).

\section{r - مراحل بروز مقاومت سيستميك اكتسابى} اين نوع مقاومت طى سه مرحله بروز مى كند. ץ-1- توليد و تجمع يروتيينهاى مرتبط با بيماريزايى (PR-proteins) : اين يروتيينها در اثر تنشهاى مختلف اعمم از زيستى مانند آلودگى به ريزجانداران و محركهاى(Inducers) آنها و غيرزيستى مانند تنش شورى و خشكى، زخم شدن مكانيكى، در كياهان توليد مىشوند (Tuzun and Bant 2006). بر اساس توالى

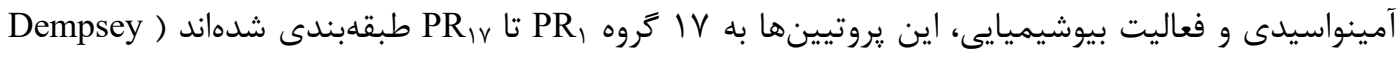

$$
\text { (et al. } 1998
$$

Oryza sativa وNicotiana tabacum ،Hordeum vulgare AArabidopsis اين يروتيينها در كياهان :PR, شناسايى شداند و داراى وزن مولكولى If IV تالودالتون و اغلب داراى محرك زيستى هستند .(Liu and Xue 2006)

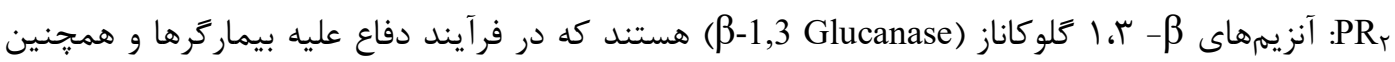
Hong and ( فرآيندهاى رشد معمول در كياه فعال هستند. وزن مولكولى آنها سب الى بَ كيلودالتون است 


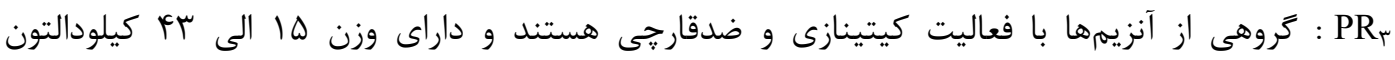
مىباشند. كيتينازها را مىتوان به دو گروه كيتينازهاى خارجى و كيتينازهاى داخلى تقسيم كرد: كيتينازهاى خارجى باعث هيدروليز باندهاى كليكوزيدى از انتهاى زنجيره مىشوند، درحالى كه اندوكيتينازها موجب هيدروليز ييوندهاى داخلى كليكوزيدى مىشوند (Saikia et al. 2005). يروتيينهاى متصل شونده به كيتين هستند. اين يروتيينها از (Chitin Binding Protein=CBP) : PR كياهانى مانند جغندرقند و سيبزمينى جداسازى شدهاند. وزن مولكولى اين گروه از يروتيينها و الى . كيلودالتون است (Yang and Gong 2002).

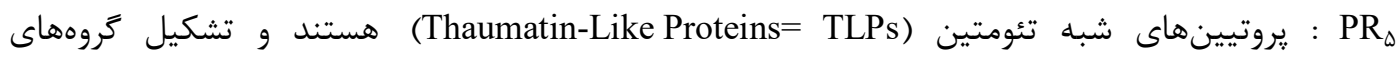
يلى يتيتيدى را مى دهند كه شباهت بسيار بالايى با تئومتين دارند. بيشتر TLPs ها داراى وزن مولكولى \1 الى هץ كيلودالتون هستند (Zamani et al. 2004). اين يروتيين داراى مزه شيرين است و اولين بار از درختجهاى در غرب آفريقا به نام Thaumatococcus daniellii جداسازى شده، و علت نامخذارى اين يروتئين نام اين كياه است (Brandazza et al. 2004). اين گروه از يروتيينها از كياهانى مانند جو، كيوى و ذرت نيز جداسازى شدهاند. اين يروتيينها داراى خاصيت ضدقارجى قوى هستند (Shatters et al. 2006). تحقيقات جديد نشان داده است كه اين يروتيينها در ساير جانداران هم وجود دارند (Mukherjee et al. 2010). يزوهش مولكولى نشان داده كه ميزان بيان زنهاى مرتبط با TLPs در كياهانى كه بلوسيله باكترىها، قارجها و الميستها آلوده مىشوند، افزايش معنى دارى ييدا مى كند (Womycetes) اين يروتيين را مىسازند، آن را به داخل آيويلاست ترشح مى كنند. بيش از • ب نوع TLP در جانوران، گياهان و قارجها شناسايى شدهاند كه خاصيت ضدقارجى دارند. سازوكارهاى ضدقارجى متفاوتى براى اين مواد ״يشنهاد شده است. افزايش نفوذيذيرى غشاى سلولى، باند شدن به بتا-كلوكان و تخريب آن، جلوكيرى از ترشح آنزيمهايى مانند زيلاناز، آلفا-آميلاز و ترييسين، از جمله فعاليتهاى ضدقارجى اين بروتيينها هستند

.(Fierens et al. 2007)

اين :روتيينهاى دفاعى هم در تكليهاىها و هم در دولٍهاىها تجمع بِيدا مى كنند و داراى فعاليت ضد ميكروبى قوى هستند (Kim et al. 2008). 
ץ-ז- تجمع و اتصال مواد در ديواره سلولى: ديواره سلولى گياه با رسوب و اتصال يلىسـاكاريدها، يـروتيينهـا، كليكويروتيينها و فنلها استحكام بيشترى مىيابد. البته تحريك سيستم دفاعى كياه مسىتوانـد زنجيـرهاى از واكنشها را كه منتهىى به ساختهشدن متابوليتهاى ثانويه در كياهان مىشـوند كـهـ بعضى از آنهـا فعاليـت يادزيستى دارند، مانند فيتوآلكسينها (Phytoalexins)، را باعث شود(Passardi et al. 2004). ץ-ז- ليگنينى شدن: بعد از سلولز فراوانترين ماده آلى در ديواره سلولهاى گياهان، ليگنين است (Theis and Lerdau 2003). ليگنين يليمرى بسيار منشعب و يِپيده از اسيدهاى آمينهاى فنيليرويان است (شكل (). ليحنينى شدن از سازوكارهاى سريع دفاعى است كه در هنگام هجوم بيمارگر، گياه از خود بروز مىدهد. ليخَنينى شدن هم در آوند آبكش و هم آوند جوبى آلوده اتفاق مىافتد. اين واكنش در شدتهاى بالاتر در گياهان مقاوم نسبت به حساس مشاهده مىشود. زمانى كه بركهاى برنج با استرين ناساز گار باكترى تلقيح شوند تركيباتى مشابه ساختار ليخنين در برگها تجمع پيدا مى كنند. از ميان ايزوآنزيمهاى مختلف آنزيم يراكسيداز تنها تعدادى در القاى عمل ليحنينى شدن و مقاومت به بيمارى نقش دارند (Giberti et al. 2012). در برگهاى اوليه گياه لوبياى Red Mexican تلقيح شده با Pseudomonas syringae pv. phaseolicola مشاهده مىشود. فعاليت يراكسيداز هم در ناحيه موردنظر در واكنش ناسازكار، به ميزان زيادى مىتواند به يراكسيداز آنيونى يس از تلقيح نسبت داده شود (Nowogórska and Patykowski 2015). امروزه بهوسيله روشهاى جديد، انتقال زن سنتزكننده ليگنين به درختان بهخصوص درختان جنگلى ميسر شده است. با

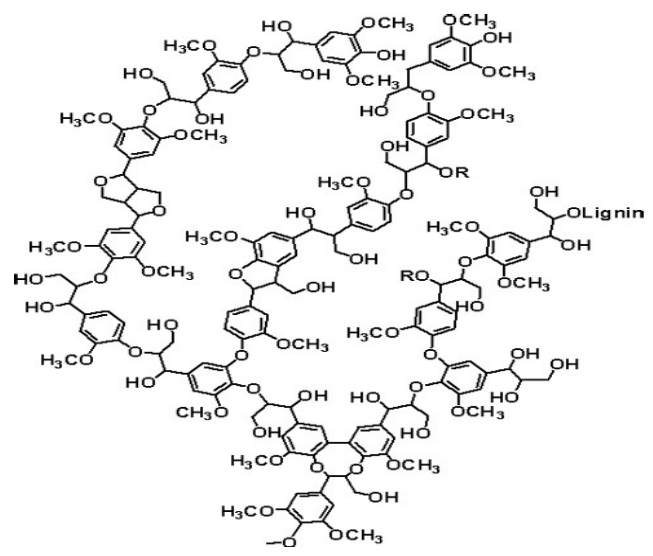

Figure 1- Lignin شكل ا- ليخنين 
استفاده از روشهاى مهندسى زنتيك مىتوان روى كيفيت ليخنين تأثير كذاشت. هدف از تغيير ليخنين افزايش ميزان آن و همجنين افزايش كيفيت آن جهت بالا بردن دفاع گياهى و همجنين قابليت برداشت آسانتر آن جهت تسهيل در فرايند كاغذسازى مىباشد. در زمينه بيوسنتز ليحنين، هدف جدا كردن آنزيم ليخنين يليمراز و زن مربوط به آن است (Ten et al. 2014). تأثير اسيد ساليسيليك(Salicylic acid) روى نشانهاى بيمارى سيتورياى بركى در ارقام گَندم حساس (اترك و كوير) و متحمل (دريا و زاگرس) در شرايط گلخانه بررسى شده است. رقم زاگرس در سطح جهار ميلىمولار اسيد ساليسيليك با كمترين شدت بيمارى و رقم اترى در سطح ه/ • ميلىمولار اسيد ساليسيليك بيشترين شدت بيمارى را در اين آزمون نشان دادند. بر اساس نتايج اين تحقيق بهترين غلظت پيشنهادى براى پֶاشش روى برگهاى گَندم r ميلىمولار است و اسيد ساليسيليك بهعنوان يك القاگر قوى براى تحريك سيستم دفاعى گياه در نظر گَرفته شد (Gholamnezhad et al. 2013). همجنين در يزوهشى ديكر با مخمر Rhodotorula mucilaginosa (A1) باعث افزايش فعاليت آنزيمهاى يراكسيداز به عنوان القاى ياسخهاى دفاعى و مهار كيك آبى سيب Penicillium expansum شده است (Gholamnezhad et al. 2011).

\section{نتيجه كيرى و وييشنهاد}

كياهان داراى سازوكارهاى دفاعى متعددى هستند، كه مىتوان آنها را با ريزجانداران يا مواد شيميايى تحريك و فعال كرد. مقاومت سيستميك اكتسابى (SAR) مهمترين نوع مقاومت القايى است، كه حفاظت مداوم و طولانىمدت عليه آلودگى در برابر دامنه وسيعى از بيمارگرها را در كياهان موجب مىشود. تجمع يراكسيداز و ديكر آنزيمهاى آنتىاكسيدان اغلب با شروع القاى مقاومت ارتباط دارد. فنيليرويانوييدها نيز متابوليتهاى ثانويه گَياهى هستند كه در مسير ساخت ليكنين و تركيبات پادزيستى فنلى تأثير دارند. اسيد ساليسيليك و اسيدجاسمونيك نيز نقش سيگنال را در شروع اين واكنشها ايفا مىكنند. اخيراً بهوسيله روشهاى مهندسى زنتيك، انتقال زنهاى دفاعى از جمله زن سنتزكننده ليحنين ميسر شده است. با استفاده از روشهاى كلونسازى و انتقال زن مىتوان محل اين زنها را در كياهان مقاوم شناسايى كرد و آنها را به كياهان حساس انتقال داد. با استفاده از نتايج تحقيقاتى كه در زمينه تركيبات دفاعى گياهى از جمله ليخنين صورت گرفته است، يِيشنهاد مىشود كه زنهايى كه در مسيرهاى دفاعى در كياهان شركت مى كنند مورد 


$$
\text { شناسايى قرار بخيرند و سيس با استفاده از روشهاى انتقال زن به كياهان حساس با صفات مطلوب منتقل }
$$

\section{References}

I. فرحبخش ف. و مساح، ا. سوسا، زنتيك مقاومت به بيمارىهاى كياهى. دانش بيمارى شناسى حياهى

2. Brandazza A., Angeli S., Tegoni M., Cambillau C. and Pelosi P. 2004. Plant stress proteins of the thaumatin-like family discovered in animals. FEBS Letters 572:3-7.

3. Dempsey D. M. A., Silva H. and Klessig D. F. 1998. Engineering Disease and Pest Resistance in Plants. Trends Microbiology 6:54-61.

4. Farahbakhsh F. and Massah A. 2015. Genetic of resistance to plant disease. Plant Pathology Science 4:64-74.

5. Fierens E., Rombouts S., Gebruers K., Goesaert H., Brijs K., Beaugrand J., Volckaert G., Van Campenhout S., Proost P., Courtin C. M. and Delcour J. A. 2007. TLX1, a novel type of xylanase inhibitor from wheat (Triticum aestivum) belonging to the thaumatin family. Biochemical Journal 403:583-591.

6. Gholamnejad J., Etebarian H. R., Roustaee A., Sahebani N. A. 2009. Biological control of apples blue mold by isolates of Saccharomyces cerevisiae. Journal of Plant Protection Research 49:270275.

7. Gholamnejad J., Etebarian H. R. and Sahebani N. 2010. Biological control of apple blue mold with Candida membranifaciens and Rhodotorula mucilaginosa. African Journal of Food Science 4:001-007.

8. Giberti S., Bertea C. M., Narayana R., Maffei M. E. and Forlani G. 2012. Two phenylalanine ammonia lyase isoforms are involved in the elicitor-induced response of rice to the fungal pathogen Magnaporthe oryzae. Journal of Plant Physiology 169:249254.

9. Gong M., Li Y., Dai X., Tian M. and Li Z. 2001. Involvment of calcium and calmodulin in the acquisition of HS inuced thermo tolerance in maize seeding. Journal of Plant Physiology 150:615-621.

10. Hong T. Y. and Meng M. 2004. Biochemical characterization and antifungal activity of an endo-1,3-3-glucanase of Paenibacillus sp. isolated from garden soil. Applied Microbiology and Biotechnology 61:472-478. 
11. Jafary H., Albertazzi G., Marcel T. C. and Niks R.E. 2008. High diversity of genes for nonhost resistance of barley to heterologous rust fungi. Genetics 178:2327-2339.

12. Kim Y. H., Kim C.Y., Song W. K., Park D. S., Kwon S. Y., Lee H. S., Bang J. W. and Kwak S. S. 2008. Overexpression of sweet potato swpa4 peroxidase results in increased hydrogen peroxide production and enhances stress tolerance in tobacco. Planta 227:867881.

13. Lange B. M., Lapierre C., Sandermann H Jr. 1995. Elicitor-induced spruce stress lignin (structural similarity to early developmental lignins). Plant Physiology 108:1277-1287.

14. Liu Q. and Xue Q. 2006. Computational identification of novel PR-1-type genes in Oryza sativa. Journal of Genetics 85:193-198.

15. Mandal S. 2010. Induction of phenolics, lignin and key defense enzymes in eggplant (Solanum melongena L.) roots in response to elicitors. African Journal of Biotechnology 9:8038-8047.

16. Marjamaa K., Kukkola E. M. and Fagerstedt K. V. 2009. The role of xylem class III peroxidases in lignifi cation. Journal of Experimental Botany 60:367-376.

17. Mohr P. and Cahill D. M. 2001. Relative roles of glyceollin, lignin and the hypersensitive response and the influence of $\mathrm{ABA}$ in compatible and incompatible interactions of soybeans with Phytophthora sojae. Physiological and Molecular Plant Pathology 58:3141.

18. Mukherjee A. K., Carp M. J., Zuchman R., Ziv T., Horwitz B. A. and Gepstein S. 2010. Proteomics of the response of Arabidopsis thaliana to infection with Alternaria brassicicola. Journal of Proteomics 73:709-720.

19. Niderman T., Genetet I., Buryere T. and Gees R. 1995. Pathogenesis-related PR-1 proteins are antifungal. isolation and characterization of three 14-kilodalton proteins of tomato and of a basic PR-1 of tobacco with inhibitory activity against Phytophthora infestans. Plant Physiology 108:17-27.

20. Niks R. E., Parlevliet, J. E., Lindhout P. and Y. Bai. 2011. Breeding crops with resistance to disease and pests. Wageningen Academic Press, Wageningen, The Netherlands, 202.

21. Passardi F., Tognolli M., de Meyer M., Penel C. and Dunand C. 2006. Two cell wall associated peroxidases from Arabidopsis influence root elongation. Planta 223:965-974.

22. Rengel D., Graham R. and Pedler J. 1994. Time-course of biosynthesis of phenolics and lignin in root of wheat genotypes differing in manganese efficiency and resistance to take-all fungus. Annals of Botany 74:471-477. 
23. Saikia R., Singh B. P., Kumar R. and Arora D. K. 2005. Detection of Pathogenesisrelated Proteins- Chitinase and â-1,3-Glucanase in Induced Chickpea: Current Science 89:659-663.

24. Senthil-Kumar M., Mysore K. S. 2013. Nonhost resistance against bacterial pathogens: retrospectives and prospects. Annual Review Phytopathology 51:407-27.

25. Shatters R. G., Boykin L. M., Lapointe S. L., Hunter W. B. and Weathersbee A. A. 2006. Phylogenetic and structural relationships of the PR5 gene family reveal an ancient multigene family conserved in plants and select animal taxa. Journal of Molecular Evolution 63:12-29.

26. Ten E., Ling C., Wang Y., Srivastava A., Dempere L. A. and Vermerris W. 2014. Lignin nanotubes as vehicles for gene delivery into human cells. Biomacromolecules 13:327338.

27. Theis N. and Lerdau M. 2003. The evolution of function in plant secondary metabolites. International Journal of Plant Science 164:93-102.

28. Truman W., de Zabala M. T. and Grant M. 2006. Type III effectors orchestrate a complex interplay between transcriptional networks to modify basal defense responses during pathogenesis and resistance. The Plant Journal 46:14-33.

33. Tuzun S. and Bant, E. 2006. The possible role of PR proteins in multigenic and induced systemic resistance. In Multigenic and induced systemic resistance in plants. 112-142. Springer US.

34. Vance C. P., Kirk T. K. and Sherwood R. T. 1980. Lignification as a mechanism of disease resistance. Annual Review of Phytopathology, 18:259-288.

35. Wang X., Tang C., Deng L., Cai G., Liu X., Han Q., Buchenauer H., Wei G., Han D., Huang L. and Kang Z. 2010. Characterization of a pathogenesis-related thaumatin-like protein gene TaPR5 from wheat induced by stripe rust fungus. Physiologia Plantarum 139:27-38.

36. Yang Q. and Gong Z. 2002. Purification and characterization of an ethylene-induced antifungal protein from leaves of guilder rose (Hydrangea macrophylla). Protein Expression and Purification, 24:76-82.

37. Zamani A., Sturrock R. N., Ekramoddoullah A. K. M., Liu J. J. and Yu X. 2004. Gene cloning and tissue expression analysis of a PR-5 thaumatin-like protein in Phellinus weirii infected douglas-fir. Biochemistry and Cell Biology 94:1235-1243. 